\title{
Levoatriocardinal vein in association with tetralogy of Fallot: a rare pulmonary to systemic connection
}

\author{
Niraj Nirmal Pandey, Mumun Sinha, Sanjeev Kumar
}

Department of Cardiovascular Radiology and Endovascular Interventions, All India Institute of Medical Sciences, New Delhi, India

\section{Correspondence to} Dr Sanjeev Kumar, sanjeevradio@gmail.com

Accepted 18 May 2019

\section{DESCRIPTION}

A 1-year-old-male child presented with cyanosis and failure to thrive. A transthoracic echocardiogram established the diagnosis of tetralogy of Fallot, and the patient was referred for a CT angiography (CTA) for further evaluation. CTA confirmed the diagnosis of tetralogy of Fallot. An anomalous venous channel $(*)$ was seen connecting the left superior pulmonary vein (LSPV) and the left brachiocephalic vein (figure 1). The LSPV and the left inferior pulmonary vein were seen draining normally into the left atrium (LA). No left heart obstructive lesions were noted.

A levoatriocardinal vein (LACV) is a rare form of pulmonary to systemic connection. Embryologically, it represents a persistent communication between the left cardinal vein and the pulmonary vein (PV), in the presence of a normal communication between PVs and LA. Most frequently, it is observed in association with left-sided obstructive lesions such as hypoplastic left heart syndrome, mitral stenosis/atresia, cor triatriatum, aortic stenosis/atresiaand aortic coarctation. ${ }^{1}$ In such cases, it serves as an alternate drainage pathway for the pulmonary venous blood, thus decompressing the LA. The presenting symptoms usually depend on the associated congenital heart disease. An isolated

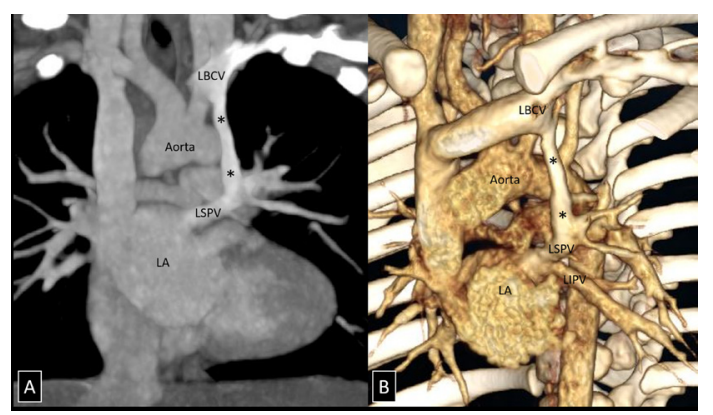

imited 2019.ing Group imited 2019. No commercial re-use. See rights and permissions. Published by BMJ.

\begin{tabular}{|l|}
\hline To cite: Pandey NN, \\
Sinha M, Kumar S. BMJ Case \\
Rep 2019;12:e230648. \\
doi:10.1136/bcr-2019- \\
230648 \\
\hline
\end{tabular}

Figure 1 Oblique coronal maximum intensity projection image $(A)$ and volume-rendered image $(B)$ depict the levoatriocardinal vein $\left({ }^{*}\right)$ connecting the left superior pulmonary vein (LSPV) and the left brachiocephalic vein (LBCV). The LSPV and the left inferior pulmonary vein (LIPV) are seen to drain normally into the left atrium (LA).
LACV may present with an asymptomatic murmur or be detected in a patient with a left-to-right shunt with a clinical suspicion of atrial septal defect. In the presence of a bidirectional shunt, the patients may present with symptoms due to paradoxical embolism and would require surgical/endovascular closure of the anomalous channel.

Very rarely, an LACV may be seen in the absence of left-sided obstructive lesions, such as in this case, where it is seen association with tetralogy of Fallot.

\section{Learning points}

- Levoatriocardinal vein (LACV) represents a persistent embryologic communication between the left cardinal vein and the pulmonary vein, in the presence of a normal communication between pulmonary veins and left atrium.

- It is frequently observed in association with leftsided obstructive lesions, such as hypoplastic left heart syndrome, mitral stenosis/atresia, cor triatriatum, aortic stenosis/atresia and aortic coarctation, serving as an alternate drainage pathway for the pulmonary venous blood and decompressing the left atrium.

- While an isolated LACV may present with an asymptomatic murmur, in the presence of a bidirectional shunt, the patients may present with symptoms due to paradoxical embolism.

Contributors NNP, MS and SK have participated sufficiently in the conception of the idea, development of the intellectual content, design, writing and final approval of the manuscript.

Funding The authors have not declared a specific grant for this research from any funding agency in the public, commercial or not-for-profit sectors.

Competing interests None declared.

Patient consent for publication Parental/guardian consent obtained.
Provenance and peer review Not commissioned; externally peer reviewed.

\section{REFERENCE}

1 Blieden LC, Schneeweiss A, Deutsch V, et al. Anomalous venous connection from the left atrium to the cardinal venous system: "levoatriocardinal vein". AJR Am J Roentgenol 1977;129:937-8. 
Images in...

Copyright 2019 BMJ Publishing Group. All rights reserved. For permission to reuse any of this content visit https://www.bmj.com/company/products-services/rights-and-licensing/permissions/

BMJ Case Report Fellows may re-use this article for personal use and teaching without any further permission.

Become a Fellow of BMJ Case Reports today and you can:

- Submit as many cases as you like

- Enjoy fast sympathetic peer review and rapid publication of accepted articles

Access all the published articles

Re-use any of the published material for personal use and teaching without further permission

Customer Service

If you have any further queries about your subscription, please contact our customer services team on +44 (0) 2071111105 or via email at support@bmj.com.

Visit casereports.bmj.com for more articles like this and to become a Fellow 